\title{
A LÍNGUA INGLESA E AS RELAÇÕES COMERCIAIS: ELEMENTOS E REFLEXÕES
}

\author{
Claudia Bittencourt Pereira* \\ Diógenes Cândido de Lima**
}

RESUMO: Já não se pode duvidar do status da Língua Inglesa (LI) como língua global, falada pelos mais diferentes povos em todo o mundo; tampouco contestar a necessidade do seu uso em variados contextos e para fins diversos. Partindo dessas considerações, discutimos neste artigo acerca do papel que a LI exerce no âmbito das relações comerciais, enfocando alguns elementos constitutivos desse universo linguístico. Iniciamos nossas ponderações trazendo o suporte teórico de autores como Crystal (1995) (2006) e Mckay (2002), dentre outros, para falarmos a respeito da LI como língua franca, língua internacional ou língua global, ou "World English", esta última denominação trazida por Rajagopalan (2012). Em seguida, traçamos um breve histórico acerca da origem do comércio no mundo e as possibilidades comunicativas advindas dos contatos por ele propiciados. E, para concluir as nossas reflexões, abordamos a questão das barreiras linguísticas na interação em LI, ao mesmo tempo em que tratamos da linguagem pelo seu enfoque cultural por acreditarmos que língua, cultura e barreiras linguísticas são tópicos indissociáveis no tocante aos estudos linguísticos. Para embasar nossas argumentações a esse respeito, buscamos apoio nos trabalhos de autores como Lima (2004), Gerson (2011), Brown (1980) e outros.

PALAVRAS-CHAVE: Relações comerciais; Língua Inglesa; Negócios (Inter)Nacionais.

\footnotetext{
* Mestranda do Programa de Pós-Graduação em Letras: Cultura, Educação e Linguagens - PPGCEL/UESB. Bolsista de Iniciação Científica (CAPES).

** Doutor em Educação pela Southern Illinois University at Carbondale, Estados Unidos. Professor Pleno da Universidade Estadual do Sudoeste da Bahia (Uesb).
} 
"A linguagem é como a pele, com ela eu contacto com os outros".

R. Barthes

\section{Considerações Iniciais}

Tomando a epígrafe como ilustração, iniciamos as nossas reflexões acerca do papel que a Língua Inglesa, doravante LI, exerce no mundo atual ${ }_{s}$ particularmente no mundo dos negócios, contemplando-a como mediadora de contatos entre os mais diferentes povos, nos mais diversos recantos do globo. O presente artigo é o resultado parcial da nossa dissertação, ainda em fase de elaboração, mas com resultados parciais. ${ }^{1}$ As ponderações contidas neste trabalho resultam de observações feitas ao longo de um período como professora de Inglês Instrumental, em um curso técnico profissionalizante em TI (Tecnologia da Informação) para jovens egressos do Ensino Médio da rede pública, na cidade de Vitória da Conquista, na Bahia. ${ }^{2}$ A motivação inicial para escrever sobre o tema surgiu após refletir sobre a necessidade e utilidade do uso da LI por esses jovens ao se lançarem no mercado de trabalho. Percebendo como de fundamental importância a tarefa de preparação dos estudantes para os desafios da vida em sociedade, reforçamos as palavras de Bagno (2002) quando diz que

o objetivo da escola, no que diz respeito à língua, é formar cidadãos capazes de se exprimir de modo adequado e competente, oralmente e por escrito, para que possam se inserir de pleno direito na sociedade e ajudar na construção e na transformação dessa sociedade, é oferecer a eles uma verdadeira educação linguística. (BAGNO, 2002 , p. 80)

Ao pensar que esses estudantes aprendiam a LI naquele curso como preparação para o trabalho, nasceu a ideia de expandir os estudos acerca do tema da LI nas relações comerciais e de outros pontos subjacentes, que listamos no parágrafo seguinte. Tendo verificado que havia a possibilidade de pesquisar a LI, mais detidamente no que concerne às

\footnotetext{
${ }^{1}$ Mestrado em Letras: Cultura, Educação e Linguagens (PPGCEL) - Universidade Estadual do Sudoeste da Bahia - UESB. Turma 2017.

${ }^{2}$ Curso Profissionalizante de Tecnologia da Informação: Suporte Técnico/ CETEB. Ano 2009.
} 
relações de negócios, no próprio meio em que vivemos - uma cidade do interior da Bahia -, nasceu nosso objeto de pesquisa para o Mestrado.

O município de Vitória da Conquista está localizado na região Sudoeste do Estada da Bahia - Brasil, com uma população de 348.718 habitantes $^{3}$, o que a classifica como a terceira maior cidade do Estado em termos populacionais. Nas primeiras décadas do século passado $(\mathrm{XX})$, sua economia apoiava-se basicamente na agropecuária. Com o crescimento demográfico natural, o comércio tornou-se outa atividade forte e dinâmica no município. Hoje, a região já conta com um polo industrial, evidenciando um setor socioeconômico pujante. Graças a esse perfil, o nosso trabalho de pesquisa tornou-se possível. Contamos com 04 (quatro) colaboradores, divididos entre empresários do ramo da indústria, comércio e serviços em TI, com experiência no uso da LI em situações diversas, dentro e fora do Brasil. Os resultados obtidos através dos relatos de viagens e de trabalho dos colaboradores da pesquisa apontaram para alguns elementos que compõem o universo das relações linguísticas travadas no dia-a-dia por esses profissionais. Dentre esses elementos, destacamos: o comércio, a LI como língua global, as barreiras linguísticas e a importância da cultura no saber linguístico.

A economia mundial globalizada proporciona uma dinâmica de relações entre os países onde a linguagem é o passaporte para a consecução de variados negócios entre povos dos mais diferentes lugares do planeta. Para tanto, faz-se necessária a comunicação contínua que visa diversos fins, propiciada pela função interativa da língua, em que as pessoas exercem papéis de ouvintes/falantes (FURTADO DA CUNHA 2003, p. 1), em um processo que obedece a normas e convenções sociais (DIK 1989, p. 8-9). A LI alcançou e detém o status de língua global(izada) num processo em que acompanha a humanidade em suas mudanças dinâmicas e incessantes. Presentemente, é o idioma indispensável também no cenário econômico mundial, sendo utilizado tanto por países avançados, quanto por aqueles de economia menos desenvolvida, pois “[...] nos tempos da globalização, o inglês

${ }^{3}$ Conforme IBGE - Estatísticas (Censo 2017). 
se dissemina por todas as esferas de atividades sociais". (ASSIS-PETERSON \& COX, 2007, p. 3).

A respeito da trajetória de expansão da LI, Mckay (2002, p. 15-16) declara que, no passado,

A maioria das inovações criadas para a indústria era de origem britânica, o que resultava em novas terminologias e expressões inglesas para os avanços científicos e tecnológicos. Aqueles que queriam aprender sobre essas inovações precisavam do inglês para compreender a nova terminologia e para conversar com os inventores e manufatureiros falantes do inglês. (grifo nosso)

Em concordância com o excerto da autora, e mais explicitamente com relação ao segmento destacado, constatamos que o conhecimento da LI no mundo globalizado em que vivemos, de comunicação e relações dinâmicas, é fator de vital importância, significando que, ser proficiente na língua é sinônimo de ter bom desempenho na profissão e nas relações sociais e, portanto, nas transações comerciais.

$\mathrm{Na}$ atualidade, aquele que quiser e necessitar aprender e utilizar as inovações tecnológicas, por exemplo, precisa aprender a língua-código utilizada nesse meio. Alguns profissionais detêm o conhecimento de mais de uma língua estrangeira. Como explicita Miccoli (2011, p. 178): “Um profissional com essa habilidade é disputado por ter acesso à pluralidade e diversidade de conhecimento no mundo, tendo capacidade de interagir e de ação”. Assim também acontece na esfera dos negócios, como registraram os relatos dos colaboradores da pesquisa sobre suas experiências, revelando que, apesar da presença do espanhol e do mandarim nos eventos de que participaram, o conhecimento do inglês é crucial para compras e vendas de produtos e manutenção de máquinas, pois ele tem predominância concreta entre os falantes. Ou seja, o inglês é a língua do mundo dos negócios na atualidade.

\section{A LI e o mundo contemporâneo}

"Uma língua não obtém um status genuinamente global até desempenhar um papel importante que seja reconhecido em todos os países”. Essa declaração de Crystal (2004, p. 20), escrita há mais de dez anos, mas ainda tão atual, evidencia uma das características - o 
reconhecimento - que fizeram do Inglês uma língua franca, internacional, global, dentre outras nomenclaturas dadas por diversos estudiosos para denominar o inglês como uma língua comum. No nosso caso, preferimos utilizar o último termo (global) como referência. Mas, até que a LI atingisse tal status, ela percorreu um longo caminho, sendo modificada em uns pontos, preservada em outros, fundindo e se difundindo, como acontece com qualquer outra língua. É sobre esse percurso que faremos a seguir uma pequena síntese a título de uma melhor compreensão.

Quando os povos germânicos ${ }^{4}$ vieram do norte da Europa, a partir do século V, e ocuparam as Ilhas Britânicas, encontraram o povo Celta, os habitantes nativos daquela região, que chegaram ali por volta do primeiro milênio a.C. Esses povos sofreram antes a dominação dos Romanos, que invadiram as ilhas aproximadamente em 43 a.C. A (s) língua (s) falada (s) pelo povo Celta pertenciam à família linguística indo-europeia e, apesar de terem se fixado nas ilhas por cerca de um milênio, a influência da língua céltica não é tão marcante na LI contemporânea. O Latim, com apenas meio milênio de permanência, deixou marcas maiores na língua. Com o fim do domínio de Roma, começa o reinado dos anglo-saxões na Grã-Bretanha. Esse é o período do Old English (inglês antigo), que vai até meados do século XII. O segundo período, o Middle English (Inglês Médio), que vai até metade do século XV, tem a característica de ter sido rápido e de ter enfrentado uma variedade linguística, com a presença importante do Francês e do Latim. O Modern English (Inglês Moderno) teve 2 fases: a primeira, marcada pelo advento da imprensa de William Caxton em 1476, e a segunda, que predominou no século XVIII, e que, ao final desse período, já se assemelhava grandemente ao Inglês atual (CRYSTAL, 1995).

A segunda metade do século XVIII é marcada pela Revolução Industrial, acontecimento nascido das conquistas tecnológicas e científicas da Inglaterra e dos Estados Unidos, as duas potências mundiais da época. (MAFRA, 2004). Esses acontecimentos deram início

${ }^{4}$ Frísios, anglos, saxões, jutos e outros. 
a uma larga expansão comercial. Como o idioma dos países geradores das marcantes mudanças no cenário mundial era o Inglês, não é difícil imaginar que os contatos entre os povos de diferentes nações e línguas eram feitos no idioma desses precursores. Daí a rápida disseminação da LI pelo mundo, motivada ainda pelo fenômeno da globalização. Nessa trajetória a LI passa a ser não apenas um idioma falado como língua oficial ou semioficial de alguns países, mas também passa a ser prioridade no ensino de língua estrangeira por todo o globo (CRYSTAL, 2006), se desterritorializando, se mesclando, até se transformar no "World English" (RAJAGOPALAN, 2012), uma língua que pertence a todos que a falam, uma língua sem fronteiras como o próprio mundo.

Seja a LI adquirida ou aprendida, tenha ela o caráter de língua materna ou não, seja ela aprendida como segunda língua ou como língua estrangeira, o fato é que ela está presente em nosso cotidiano, corriqueiramente, como se fizesse parte da nossa herança linguística. O seu papel de atuação na sociedade varia tanto quanto os motivos e a necessidade do seu uso, que vão “do comércio até a pesquisa, passando pelas redes de transmissão de notícias" (MOITA LOPES, 2003, p. 4). Presente em muitos e variados contextos, percebese a necessidade do seu conhecimento, "a fim de se modernizar, de adquirir saber científico e acesso à tecnologia, e de se tornar mais competitivo profissionalmente no mercado mundial, dentre outras coisas”. (LIMA, 2004, p. 7), (tradução nossa). O mercado de trabalho e as relações comerciais tornam-se cada vez mais internacionalizadas e são provas contundentes de que a globalização da economia promove e difunde a globalização linguística ou, talvez pudéssemos pensar que seja o inverso - que talvez essa dinâmica global da língua (gem) é que torne possível as transações comerciais entre os povos.

A seguir, faremos uma breve retrospectiva histórica para entendermos os primeiros passos das relações comerciais no mundo, refletindo sobre o papel da língua (gem) como instrumento essencial nesse processo. 


\section{O comércio - um sistema de trocas mediado pela língua (gem)}

Como definição livre podemos dizer que comércio é a atividade de troca (com moeda ou não) de produtos e serviços, com o fim de obter lucro. Como tantos outros fatos, é impossível determinar precisamente o momento histórico do surgimento do comércio no mundo. As práticas comerciais são muito antigas e datam mesmo do período primevo da humanidade, cujo sistema estava longe de envolver dinheiro como moeda de troca. No passado, as transações comerciais eram feitas através de um processo de permuta, chamado escambo.

No início do desenvolvimento do comércio moderno, os produtos eram intercambiados diretamente nos postos de troca, sendo que na época as moedas não tinham a credibilidade financeira para serem universalmente aceitas. Era a fase do escambo. (NOVAES: 2001, p. 1).

Com o passar do tempo, as coisas evoluíram, as cidades foram sendo construídas, as demandas por produtos diversificados foram surgindo e modificando a oferta das mercadorias, até atingirmos o período das colonizações, quando surgiram as primeiras manifestações de comércio em troca de dinheiro. Relativamente ao período denominado de Idade Moderna, as atividades comerciais passaram por diversas fases, obedecendo à dinâmica da civilização; em um primeiro momento os comerciantes eram mercadores (sem a noção de organização sistemática das atividades), depois passaram a ser negociantes (período da mecanização), e, por fim, tornaram-se industriais (domínio da ciência da máquina). (EPOCH TIMES, 2014). Na fase atual em que vivemos (início do século XXI), talvez possamos denominá-los de tecnológicos. É a era da cibernética, da revolução digital.

As atividades comerciais desenvolvidas entre os países denominam-se comércio internacional ${ }^{5}$. Nesse ponto, abrimos a reflexão sobre a importância da linguagem no comércio, em um mundo de tecnoglobalismo e migrações massivas (MIGNOLO, 2009, p. 229),

\footnotetext{
${ }^{5}$ Expressão comumente utilizada como “comércio exterior”, mas que difere desta acepção. Comércio internacional são as operações comerciais realizadas entre países diferentes; enquanto que comércio exterior são as 
sem esquecermos a sua presença inerente a todas as épocas. A língua (gem) sempre exerceu papel preponderante na interação entre os povos. Com o fenômeno da globalização, tornamo-nos todos membros de uma comunidade internacional e, embora vivamos em países diversos e falemos línguas distintas, em determinados contextos necessitamos de um idioma comum a ser partilhado a fim de que todos se entendam. Essa universalidade linguística, na atualidade, é exercida pela LI. Com o fenômeno de um mundo global, o sentido de fronteiras físicas desaparece, as nações abrem as portas e o aproximar dos povos faz nascer uma comunicação dinâmica e interativa.

Segundo Crystal (2004, p. 23), a preeminência da LI como língua global deve-se, sobretudo, “ao poder das pessoas que a falam”. Na concepção do autor, língua como instrumento linguístico global está intimamente ligada à questão de poderio, de domínio. $\mathrm{O}$ autor cita alguns campos nos quais o inglês tornou-se primazia no mundo e, dentre eles, está a economia.

Em 1914, a Grã-Bretanha e os Estados Unidos estavam investindo, juntos, mais de 10 bilhões no exterior - três vezes mais que a França e quase quatro vezes mais que a Alemanha. O "imperialismo econômico" resultante trouxe uma nova dimensão ao equilíbrio do poder linguístico. "O dinheiro fala" era a metáfora principal - e a língua em que ele mais falava era o inglês. (Ibid.pg. 25)

A metáfora citada no fragmento acima faz referência ao poder econômico, um dos domínios sobre os quais repousa a LI no atual momento, fazendo dela uma superpotência, e, inquestionavelmente, a língua do mundo dos negócios. Durante as viagens por países do continente europeu, asiático e Américas, os colaboradores dessa pesquisa se depararam com as mais diversas oportunidades de interação com seus pares. Eles relataram ainda a respeito de eventos internacionais em território brasileiro, nos quais o uso da LI, a despeito da presença de outros idiomas, não pode ser dispensado, uma vez que os seus falantes (de LI) geralmente não conhecem ou não se interessam por conhecer o idioma português. 
Esse fato impulsiona os empreendedores a buscar o aprendizado da LI a fim de manterem uma comunicação que lhes possibilite chegar aos objetivos por eles almejados, como a compra de máquinas e insumos para a produção industrial, e a importação de produtos e serviços dos países estrangeiros para as áreas de comércio e prestação de serviços. A pesquisa revelou que, além do Inglês, também é possível encontrar a presença de outros dois idiomas nos eventos de que participam os entrevistados: o espanhol e o mandarim; entretanto, a supremacia de uso é da LI, a língua-código do mundo globalizado.

A próxima seção dedica-se a apresentar dois elementos que são partes integrantes do universo linguístico e que se manifestam nas experiências comunicativas relatadas na pesquisa: as barreiras linguísticas e a cultura.

\section{Barreiras linguísticas e cultura: tópicos imanentes à língua (gem)}

Falar uma língua estrangeira pressupõe o enfrentamento de certas situações inesperadas que podem pegar qualquer pessoa de surpresa e, muitas vezes, criar mesmo um bloqueio no falante. É natural que nas nossas interações linguísticas haja momentos desafiadores a vivenciar e, certamente, vai haver inúmeros acontecimentos que fugirão ao controle do mais hábil falante, afinal de contas estamos lidando com pessoas diferentes, falantes de uma língua distinta daquela à qual estamos acostumados desde a aquisição da linguagem, a nossa língua materna. Esses entraves que podem ocorrer durante a comunicação são as barreiras linguísticas.

A esse respeito, Lima (2012) esclarece:

As barreiras linguísticas acontecem quando duas pessoas que falam línguas diferentes, ou até a mesma, não conseguem se entender. Tal problema na comunicação pode ocorrer tanto da parte do emissor quanto do receptor da mensagem. (p. 254, tradução nossa) ${ }^{6}$

\footnotetext{
6 "Language barriers occur when two people who speak different languages, or even the same, cannot understand each other. Such a problem in communication may occur at either the sender's side or the receiver's side of a message".
} 
Como declara o autor, até mesmo falantes de uma mesma língua podem vir a experimentar algum tipo de entrave na comunicação, tais são as variedades regionais, as expressões idiomáticas, as variações existentes no léxico, dentre outras particularidades linguísticas. As barreiras existentes no ato da comunicação podem acontecer nos mais diversos momentos, nas mais diversas situações, inclusive nas relações de trabalho, e afetar de maneira negativa a experiência da comunicação. ${ }^{7}$ Sem dúvida alguma, quanto maior o nível de conhecimento da língua estrangeira, menor a possibilidade de que os falantes (emissores e receptores) sofram embaraços no processo de interação. Mas apenas conhecer a língua não pressupõe a infalibilidade dos comunicantes, pois há outros fatores importantes que também interferem no processo comunicativo, os fatores culturais.

\section{Sobre o estudo}

Em 2017 começamos a pesquisa de Mestrado, ainda em andamento, com profissionais locais, das áreas do comércio, indústria e Tecnologia da Informação (TI), os quais já possuem experiências de contato com a LI de forma bastante frequente. O intuito da investigação foi coletar informações acerca do processo de interação comunicativa que os participantes vivenciam, dentro e fora do Brasil, por ocasião das suas transações comerciais com estrangeiros. Eles foram convidados a responder a um questionário com perguntas predefinidas, narrando as suas experiências profissionais e pessoais com o Inglês. Pelo fato de termos optado pelas narrativas em forma de relatos livres, concluímos que a descrição e análise iriam se estender em demasia. Por esse motivo, o inventário de colaboradores conta com apenas 04 (quatro) profissionais, cuja faixa etária varia de 25 a 52 anos, todos do sexo masculino. Nesse sentido, consideramos a quantidade de participantes suficiente para a análise do corpus. Dois deles já possuem nível intermediário de proficiência na LI (denominaremos de C1 e C2); o terceiro consegue se comunicar com certa dificuldade (C3), e o último deles não sabe falar o idioma (C4). Assim, o contato frequente que eles mantêm

${ }^{7}$ Ibidem. p. 256. 
com falantes de LI, seja no Brasil ou em outros países para onde viajam a negócios, são ocasiões para C1 e C2 testarem os conhecimentos adquiridos; para C3, servem como incentivo para buscar conhecer mais a fundo o idioma; e, no caso de $\mathrm{C} 4$, houve a necessidade da utilização de tradutores para concretizar a comunicação nas ocasiões citadas, fato que provocou nele a vontade de aprender o idioma. Os relatos feitos por cada um deles, no tocante às experiências vivenciadas, diferem de acordo com o nível de domínio/conhecimento do idioma inglês, e variam desde o vocabulário (discernimento de palavras), até as questões de ordem cultural.

Dentre os elementos mencionados no resumo deste trabalho, apresentamos aqui dois, que já foram parcialmente analisados. A pesquisa revelou como concreta: a) a necessidade da LI para a realização de negócios (inter) nacionais e b) a importância de se conhecer a cultura do outro como forma de restringir a ocorrência das barreiras linguísticas. A seguir, ilustramos as nossas reflexões com breves passagens dos relatos da pesquisa.

\section{a) A LI como motor da economia mundial}

A realidade de um mundo globalizado e plural manifesta-se em todos as esferas da vida. No tocante ao mundo dos negócios, a importância da comunicação (inter) nacional é elementar na realização das mais diversas transações comerciais entre os países, e conhecer a língua mediadora desses serviços é, sem dúvida alguma, um diferencial que transforma a vida de quem a utiliza e torna favoráveis os resultados almejados, como atestam os relatos:

> Falando sobre a importância de saber a LI para a realização de negócios com fornecedores estrangeiros.

C1 - " Foi satisfatório porque quando a transação é feita da melhor forma possível e que os dois lados saiam ganhando, então o trabalho foi bem feito, a comunicação foi tida com sucesso".

C2 - "Sempre é possível melhorar. Eu acho que não é totalmente satisfatório, não. Eu, na verdade, sei o inglês... me viro, mas não tenho essa fluência que eu queria ter, né? A gente não teve uma imersão, né? Aí acaba que você vai usando pouco, aí você vai até enferrujando algumas coisas”. 
Dentre os fatores que podem interferir positiva ou negativamente a seu favor, quando o contato é feito com alguém que fala uma língua diferente da sua, é o conhecimento da língua estrangeira do seu interlocutor. Quando C1 aponta seus resultados como satisfatórios e C2 afirma o contrário, é que o primeiro já possui um bom conhecimento da LI, frequentou cursos de idioma, o que facilitou muito sua vida empresarial; enquanto que o segundo entrevistado declarou ter pouca instrução no idioma, o que cria situações de limitação constante, o que reflete em seu trabalho. O resultado de qualquer empreendimento, seja ele físico ou intelectual, deve passar pela interação entre as partes envolvidas. O que o profissional almeja numa rodada de negócios, é que os seus esforços sejam plenificados com êxito. E para isso, a comunicação é um fator preponderante.

$>$ Falando da frequência do uso da LI para o trabalho.

C1 - “ Utilizo a todo momento. Porque as peças e a negociação não paga (sic) só no momento que faz... que a gente faz a transação comercial. A mercadoria, quando chega aqui no Brasil, tem todo um trâmite que é o desembaraço da mercadoria. O desembaraço da mercadoria é feito através de alguns documentos internacionais, como, por exemplo, um invoice, que no Brasil seria uma fatura, uma BL, né? E eu tenho que entrar em contato com o despachante, o responsável, normalmente com os chineses ou alemães, que foram nossos fornecedores, e as próprias peças que estão todas catalogadas em inglês".

C2 - “[...] em ligação telefônica, por exemplo, é mais raro, acontece também, mas é mais raro, porque a gente tem mais dificuldade. Eu, às vezes quando quero falar, prefiro usar o WhatsApp, porque aí você... o inglês quando você ouve pelo telefone é terrível pra você comunicar, e no WhatsApp não, você faz, você corrige... [...] Eu prefiro o e-mail ou WhatsApp do que o telefone, telefone não... não... principalmente se for conversar com o chinês, ele tem um acento todo diferente, não dá”.

A experiência dos colaboradores da pesquisa com a LI evidencia diversos momentos de necessidade do uso da língua. Eles se comunicam desde que embarcam no voo internacional rumo às terras estrangeiras, até o momento das grandes feiras internacionais, 
das quais participam profissionais do mundo inteiro. Vivenciam ainda oportunidades, até mesmo no Brasil, de resolver trâmites burocráticos, como complemento das negociações, tudo em LI. Utilizam tanto a forma falada quanto a escrita para se comunicar.

> Falando sobre a LI como a língua do mundo dos negócios.

C1 - “Sem dúvida, sem dúvida. [...] O maior credor americano é a China, então eles (os empresários) vão querer saber com quem eles estão lidando, né? E eu acredito sim, porque onde eu trabalhei, nos setores que eu trabalhei, sempre (se) utilizou só o inglês. Até mesmo quando eu viajei, né, a passeio pela Europa, eu utilizei o inglês e todo mundo fala o inglês".

C2 - "É, sim. Porque tudo quanto é negócio que você faz, em qualquer parte do mundo... você vê os manuais, tem em outras línguas também, mas esses países todos têm o inglês como a segunda língua. Quando eles comunicam por escrito com você, eles comunicam em inglês. Eu nunca recebi um e-mail em espanhol".

Os colaboradores registraram a presença de outras línguas durante as viagens a eventos (inter) nacionais e também ao receberem visitantes estrangeiros aqui no Brasil. Segundo os relatos, o espanhol é a segunda língua que mais aparece nos eventos, seguida do mandarim, pelo alto volume de negociações com os chineses. Porém, na finalização dos negócios, a LI tem supremacia.

\section{b) A questão cultural também se senta na mesa de negociações}

$>$ Falando sobre a importância de se conhecer a cultura dos países para onde se vai negociar

C1 - "Sim, é muito importante... importante mesmo. [...] Aperto de mão, na China, é praticado abertamente, a interação é a do mundo ocidental, eles querem vender, eles querem se adequar a seu modo de vida, não importa quem está comprando deles, o interesse é o comercial, eles vão fazer de tudo pra que você se sinta como se estivesse no Ocidente. $\mathrm{Na}$ Coréia do Sul, mesmo que você está comprando, você deve respeitar alguns limites, né? A pessoa geralmente não quer apertar a sua mão, faz aquela reverência, entendeu? [...] E lá 
tem o respeito por idade. Eu posso ter a mesma faixa etária que outra pessoa, com diferença de 1 ou 2 anos, mas essa pessoa sempre vai me respeitar porque eu tenho 1 ou 2 anos a mais que essa pessoa. E isso é muito importante na hora de fechar um negócio, se sentar na mesa de negociação, porque se você está falando com uma pessoa, mesmo que ela esteja bem próxima de sua idade, mas você tem que falar com ar de respeito por aquela pessoa; na cultura deles sempre vai existir o respeito por quem é mais velho”.

C2 - "Pra te dizer a verdade, antes de viajar pra os lugares eu dou uma lida no... (guia turístico) pra ver os pontos interessantes, porque a gente não viaja só a trabalho, nem só a lazer. Aí então eu dou uma lida pra ver como é, aí já sei a história... porque às vezes você fala uma coisa daí ofende, tal. Por exemplo, você chamar um chinês, japonês, de raça amarela, é uma ofensa. Dizer que coreano, japonês e chinês é tudo a mesma coisa, eles se ofendem".

Defendemos mesmo o pensamento de que os aspectos culturais de um povo não podem ser dissociados dos fatores linguísticos. C1 comprova esse fato ao dizer: "E isso é muito importante na hora de fechar um negócio, [...] O respeito pela cultura do outro, quem diria, dita regras na mesa de negociações. C2 demonstra o cuidado em se conhecer a história do outro antes de viajar, ciente de que, ao se ignorar os aspectos culturais de um povo, podese criar entraves, barreiras, que podem dificultar ou mesmo impedir a conquista dos objetivos traçados. Assim, os colaboradores demonstraram saber que, ao fazer as malas rumo aos países estrangeiros ou dentro do seu próprio país, a ferramenta imprescindível a ser adicionada à bagagem não será apenas a língua. Ela estará acompanhada por outros elementos essenciais ao saber e que responderão pelo sucesso da sua empreitada.

As dificuldades linguístico/culturais que podem ocorrer entre pessoas de países e línguas diferentes, estão em conformidade com o que pontua Gerson (2003, apud LIMA, 2012, p. 254) “... teremos momentos de mal-entendidos devido às diferenças culturais que 
atribuem palavras diferentes a coisas diferentes ou significados diferentes para frases similares". (Tradução nossa) ${ }^{8}$. Nesse sentido, constatamos que as barreiras linguísticas estão intimamente relacionadas às barreiras culturais e vice-versa, provando que língua e cultura são faces indissociáveis da mesma moeda linguística. As ocorrências com as barreiras linguísticas e culturais podem acontecer em diversos momentos na vida social, como em viagens, nas relações interpessoais, no trabalho, nas comunicações via internet (em que o uso do jargão próprio do ambiente virtual demanda conhecimento), na linguagem corporal/gestual, etc. Notadamente nas relações de trabalho, que é a esfera da nossa pesquisa, esses entraves podem afetar de tal modo a comunicação a ponto de prejudicar ou mesmo impedir o andamento e a realização de negócios. De forma contrária, uma boa comunicação, baseada no conhecimento do modus vivendi do outro, pode criar laços duradouros de empatia e respeito, facilitando as relações comerciais overseas?

O homem é um ser social e, como tal, vive em constante interação com o outro. A partir desse processo recíproco, compartilham as conquistas materiais e imateriais pertencentes a cada grupo. Como comenta Campos e Silva (2010, p. 236-237) “A vida humana é um processo contínuo de comunicação. Esse é o canal pelo qual a cultura é transmitida em cada sociedade, constituindo-se uma das necessidades básicas da pessoa humana, do ser social". Alguns autores como Freire (1979) e Kramsch (1998) conceituam cultura, demonstrando seu caráter de representante essencial de cada povo. O sociólogo e filósofo francês Edgar Morin (2002) a descreve da seguinte forma:

A cultura é constituída pelo conjunto de saberes, fazeres, regras, normas, proibições, estratégias, crenças, ideias, valores, mitos que se transmite de geração em geração, se reproduz em cada indivíduo, controla e existência da sociedade e mantém a complexidade psicológica e social. (MORIN: 2002, p. 56)

\footnotetext{
8 “... we will have moments of misunderstanding because of cultural differences that assign different words to different things or assign different meaning to similar phrases”.
}

${ }^{9}$ Além-mar. 
A partir dessa definição, é possível perceber a cultura em um sentido amplo, dotada de uma característica inata que assinala um povo e lhe confere um sentido próprio, de uma identidade toda particular do ser social que é. Fazendo um contraponto entre língua e cultura, Brown (1980, p. 128) assevera que "cultura é algo que está profundamente enraizado em cada fibra de uma pessoa, mas língua - o meio de comunicação usado pelos membros de uma certa cultura - é a sua expressão mais visível e disponível", nesse sentido, a cultura é expressa através da língua que, por sua vez, faz parte da expressão cultural de determinado grupo.

O entendimento de que língua e cultura são campos indissociáveis para um pleno êxito comunicativo é reforçado por Lima (2012) quando assevera que

É a cultura, e não a língua, que define quem dirige-se a quem (a questão das hierarquias socioculturais), qual o código / o registro / a gramática / os vocabulários da língua devem ser usados em cada situação cultural, quando não falar, o que pode e o que não pode ser falado: os gestos, o tom e volume da voz em cada palavra, e o ritmo que acompanha o discurso (LIMA, 2012, p. 178).

Sendo assim, ao falarmos de barreiras linguísticas, estamos evocando a questão dos aspectos culturais intrínsecos à língua. As barreiras no processo comunicativo em uma língua estrangeira, e também em língua materna, estão diretamente ligadas, não apenas às questões de ordem linguístico-gramaticais em si, mas ao conhecimento da dimensão cultural do povo que a fala. Se não existir a competência comunicativa intercultural - cross-cultural communication - haverá prejuízos no processo comunicativo. Quando a comunicação é intercultural as línguas e culturas se abraçam em reciprocidade de respeito e compartilhamento de manifestações, tornando-as mais ricas, fortalecendo suas raízes para serem lançadas à posteridade.

\section{Considerações finais}

As reflexões feitas neste trabalho são uma breve síntese de assuntos muito importantes e atuais do mundo globalizado em que vivemos. As pessoas sentem cada vez mais necessidade de se relacionarem umas com as outras em todas as partes do mundo e o 
estreitamento das fronteiras geográficas encurta as distâncias e facilita esses intercâmbios. A línguas e as culturas se interconectam constantemente.

A pesquisa demonstrou que, ainda que haja a presença de outras línguas, como o espanhol e o mandarim, na esfera dos negócios, o uso do inglês é absoluto, como constata Ortiz (2006):

A globalização declina-se preferencialmente em inglês. Digo, preferencialmente, pois a presença de outros idiomas é constitutiva de nossa contemporaneidade, mesmo assim, uma única língua, entre tantas, detém uma posição privilegiada. (Ortiz, 2006, p. 17)

No mundo contemporâneo o que vale é o aprender mediante as demandas que a própria vida apresenta. Com a declaração de que "O caráter relacional da vida impõe, ao ser humano, o estabelecimento contínuo de vínculos físicos e simbólicos com tudo aquilo a que se liga, fazendo-o constituir-se a partir de diversas raízes" (OLIVEIRA; OLIVEIRA, 2007, p. 13) os autores traduzem a natureza dinâmica das relações humanas nas quais o compartilhamento do patrimônio imaterial entre as pessoas não as desobriga de preservarem sua própria identidade.

Considerando a importância e a necessidade da LI para o mundo dos negócios, e diante dos relatos obtidos com os profissionais pesquisados, acreditamos que investir na aprendizagem desse idioma seja medida capaz de alterar positivamente os resultados das atividades comerciais, bem como impulsionar o mercado de trabalho. Esperamos que essas breves análises do tema proposto possam instigar novas e mais aprofundadas reflexões e pesquisas, uma vez que, falar sobre interações linguístico-culturais em um mundo de rápidas e constantes mudanças é tarefa essencial para entendermos a nós e aos outros.

\title{
THE ENGLISH LANGUAGE AND COMMERCIAL RELATIONS: ELEMENTS AND REFLECTIONS
}

\begin{abstract}
The status of the English Language (EL) can no longer be doubted as the current global language, spoken by the most different peoples all over the world; nor does it challenge the necessity of its use in various contexts and for various purposes. Based on these considerations, we discuss in this article about the role that EL plays in the commercial relations sphere, focusing on some constituent elements of this linguistic universe. We start our ponderations by bringing the theoretical support of authors like Crystal (1995) (2006) and Mckay (2002), among others, to talk about
\end{abstract}


EL as a lingua franca, international language or global language, or "World English", this last denomination brought by Rajagopalan (2012). Then, we draw a brief history about the origin of the commerce in the world and the communicative possibilities coming from the contacts that it propitiated. And, to conclude our reflections, we address the issue of language barriers in EL interaction, while at the same time we treat language by its cultural focus because we believe that language, culture and language barriers are inseparable topics in language studies. To base our arguments in this regard, we seek support in the works of authors such as Lima (2004), Gerson (2011), Brown (1980) and others.

KEYWORDS: Commercial relations. English Language. (Inter) National Business.

\section{REFERÊNCIAS}

A língua inglesa, a economia e o comércio. Disponível em: <https://www.ef.com.br/epi/insights/english-economics-and-trade>. Acesso em: 25 jun. 2018.

ASSIS-PETERSON, Ana Antônia da; COX, Maria Inês Pagliarini. Inglês em tempos de globaliz̧ação: para além de bem e mal. Calidoscópio. v. 5, n. 1, 2007.

BAGNO, M. A inevitável travessia: da prescrição gramatical à educação linguística. In: BAGNO, M.; STUBBS, M.; GAGNÉ, G. (Org.). Lingua materna: letramento, variação \& ensino. São Paulo: Parábola Editorial, 2002. p. 13-84.

BORGES, Camila Alves. Comércio, comércio internacional e comércio exterior. Qual a diferença? Artigos. 2011. Disponível em: < http://www.administradores.com.br/artigos/tecnologia/comercio-comercio-internacional-e-comercio-exterior-qual-a-diferenca/54477>. Acesso em: 16 jun. 2018.

BROWN, D. H. Principles of language learning and teaching. Engkwood Ciffs N. J. United States of America. Prentice-Hall. Internacional, Inc. 1980.

CAMPOS, Lucas Santos; SILVA, Ana Claudia G. V. As funções da linguagem nos ch@ts: o "internetês" numa abordagem funcionalista. In: Fólio - Revista de Letras, Vitória da Conquista: Edições Uesb, v. 2, n. 1, 2010.

Censo Demográfico 2017. Disponível em: <https://www.ibge.gov.br/>. Acesso em 27 jun. 2018.

COX, M. I. P. ; ASSIS-PETERSON, A. A. O professor de Inglês: entre a alienação e a emancipação. Linguagem e Ensino, v. 4, n. 1, p. 11-36, 2001.

CRYSTAL, David. A Revolução da Linguagem. Rio de Janeiro: Jorge Zahar Editor, 2006.

CRYSTAL, David. The Cambridge encyclopedia of the English language. Cambridge: Cambridge University Press, 1995.

DIK, Simon C. The theory of functional grammar: the structure of the clause. Berlim: Mounton de Gruyter, p. 8-9, 1989. 
EPOCH TIMES. A evolução do comércio, 2014. Disponível em: <https://www.epochtimes.com.br/evolucao-comercio/>. Acesso em: 26 jun. 2018. Publicado originalmente na Revista de Comércio e Contabilidade, no 3, Lisboa, 25.03.1926.

FREIRE, Paulo. Educação e Mudança. 12.ed., Rio de Janeiro: Paz e Terra, 1979.

FURTADO DA CUNHA, Maria Angélica; OLIVEIRA, Mariangela Rios de; MARTELOTTA, Mário Eduardo (Org.). Linguística funcional: teoria e prática. Rio de Janeiro: DP\&A, 2003.

GERSON, Kimberley Moynahan. Language: What's Your Style? Available from: http://www.archaeolink.com/language barriers.htm. Accessed October 23, 2011.

KRAMSCH, Claire. Language and culture. Oxford: OUP, 1998.

LIMA, Diógenes Cândido de. Foreign-language learning and teaching: from theory to practice. Vitória da Conquista: Edições UESB, 2004.

LIMA, Diógenes Cândido de. Issues of cultural identity and language barriers for brazilian immigrants in South Florida. In: (Org.). Language and its cultural substrate: perspectives for a Globalized World. Campinas: Pontes Editores, 2012.

LIMA, Luciano. R. Movies and Cartoons in the EFL Classroom: For a Critical Cultural immersion. In: LIMA, Diógenes Cândido de. (Editor). Language and its cultural substrate: perspectives for a globalized world. Campinas: Pontes, 2012.

MAFRA, N. L. The English language and its global dominance in the dissemination of scholarly information: Effects on the working lives of professors at a Brazilian state university. In: LIMA, D. C. (Ed.). Foreign language learning and teaching: from theory to practice. Vitória da Conquista: Uesb, 2004. p. 137-156.

MCKAY, S. L. Teaching English as an international language. Oxford Handbooks, 2002.

MICCOLI, L. S. O ensino na escola pública pode funcionar, desde que... In: LIMA, D. C. de (Org.). Inglês em escolas públicas não funciona? uma questão, múltiplos olhares. São Paulo: Parábola Editorial, v. 1., 2011.

MIGNOLO, Walter. Local histories/global designs. coloniality, subaltern knowledges and border-thinking. Princeton: Princeton University Press, 2012.

MOITA LOPES, L. P. da. Discursos de identidades: discurso como espaço de construção de gênero, sexualidade, raça, idade e profissão na escola e na família. Campinas, SP: Mercado das Letras, 2003.

MORIN. Edgar. Os sete saberes necessários à educação do futuro. 5. ed., São Paulo: Cortez; Brasília: UNESCO, 2002.

NOVAES, Antônio Galvão. Logística e gerenciamento da cadeia de distribuição: estratégia, operação e avaliação. Rio de Janeiro: Campus, 2001. 
OLIVEIRA, Marília F. S. de; OLIVEIRA, Orlando J. R. de. Na trilha do caboclo: cultura, saúde e natureza. Vitória da Conquista: Uesb, 2007.

ORTIZ, R. Mundialização: saberes e crenças. São Paulo: Brasiliense, 2006.

RAJAGOPALAN, K. For the umpteenth time, the "native speaker": or, why the term signifies less and less in the case of English as it spreads more and more throughout the world. In: LIMA, D. C. Language and its cultural substrate: perspectives for a globalized world. Vitória da Conquista: Edições Uesb, 2012. p. 37-58.

Recebido em: 26/04/2019.

Aprovado em: 30/06/2019. 